\title{
About Participation of Institutes of Civil Society in Public Control over the Activities of Local Authorities
}

\author{
Evgeny I. Belousov ${ }^{1}$, Roman V. Gornev ${ }^{1} \&$ Tatiana N. Mikheeva ${ }^{1}$ \\ ${ }^{1}$ Mari State University, Yoshkar-Ola, Russia \\ Correspondence: Evgeny I. Belousov, Mari State University, Yoshkar-Ola, Republic of Mari El, Lenin Sq., 1, \\ 424001, Russia. Tel: 7-987-708-1548. E-mail: belashik_777@mail.ru
}

$\begin{array}{lc}\text { Received: February 21, } 2015 & \text { Accepted: March 15, } 2015 \quad \text { Online Published: April 29, } 2015 \\ \text { doi:10.5539/res.v7n8p59 } & \text { URL: http://dx.doi.org/10.5539/res.v7n8p59 }\end{array}$

\begin{abstract}
The problem of civil society, the interaction of its elements with public authorities refers to the number of fundamental scientific problems. These problems appeared with the emergence of the state and the division of society into public and private spheres of human activity. If the area of interaction between local government and NGOs in particular, some problems now solved, the scope of interaction between local government and civil society organizations and the media, remains poorly understood. In addition, it should be noted imperfection proper legislative regulation of the interaction of local authorities with public organizations and mass media. In addition to this, it is worth noting the absence of legal science integrated research directly interact public associations with local authorities. All of the above determines the relevance of the topics chosen for research. Authors analyzed forms of participation of institutes of civil society in public control over activity of local governments and formulated the concrete theoretical and practical conclusions directed on improvement of these relations.
\end{abstract}

Keywords: local government, civil society, local authorities, civil society institutions, social control, public associations, mass media

\section{Introduction}

The local authorities being a bearer of authority of public power are at the same time a form of realization of rights of citizens to accomplish local self-administration through their representatives. That is why all the local authorities, irrespective of the order of their creation, stand in relations with the population of municipality where the local authorities are the representatives of law. It is necessary to pay attention on the fact that though this kind of relation, where the authorities are the representatives of law, is supposed to provide more close ties of local authorities with population than other public authorities formations are able to propose, in real life the interaction of local authorities and local community is also quite weak, moreover this interaction is accompanied with the high level of distrust of each other. The institute of public control is urged to promote the solution of these problems. On the one hand, the institute of public control allows to gain to local community an impression about activity of the local governments, and on the other hand-to reveal shortcomings of activity of local governments for increase of efficiency of their activity in the solution of questions of local value.

Modern states as a basic fundamental principle in the legal regulation of local government put the publicity at the forefront, as a tool linking the local authorities with the residents of municipalities (Mikheev, 2014). As we believe this is the main reason why the organization of public control in fields in municipalities where the citizens can apply the statutory mechanisms of public control is of the greatest interest. In our opinion, on local level there exist more possibilities of effective application of public control which can help bring together municipal officials and local population and in such a way increase the effectiveness of their work. It is what determined the choice of the subject of the research. In this regard, Federal Law No. 212-FZ of 21 July 2014 "On basic principles of public control in the Russian Federation" (further - the Law on public control) plays a special role.

Despite relative novelty of this document, it is easy to see gaps regarding legal regulation of mechanisms of participation of institutes of civil society, first of all, mass media and public associations, in public control over the activities of local authorities. 


\section{Methods}

Methodological principle (bias) of the research is the complex of methods of scientific study of social processes, circumstances and facts. On the one hand, dialectical approach of cognition is of prevailing importance. This approach assumes that legal and social phenomena are being investigated in their historical and logical interconnection. On the other hand, the principles of scientific objectivity and historical method play a great role too. And it implies the objective and thorough analysis of factual material, taking into consideration the concrete historical situation and all the set of legal, political, economical and social factors influencing the interaction of local authorities and institutions of civil society. So, the concept and the nature of public control were investigated by means of a system method. As a result, the corresponding gaps of legal regulation were revealed. The types of public control re investigated by means of a formal and logical methods: as a result, levels of public control were determined. The comparative and legal method was used in the analysis of regulation of a legislative (law-making) initiative at the regional level. The comparative and legal method allowed to investigate the legislation of some subjects of the Russian Federation - the Republic of Mari El, Altai Republic, the Belgorod region, the Samara region, Kabardino-Balkar Republic. The historical method was applied at an assessment of the Soviet legislation regarding interaction of public associations and local councils allowed to reveal continuity of legal regulation in the matter.

\section{Results and Discussion}

Analyzing the ideas of scientists concerning the constitutional and municipal law one can note that in scientific literature you come across the following definitions of the notion "public control":

1) A kind of control exercised by a civil society aimed at assessment of work of public authorities of all the levels;

2) One of the types of social control exercised by associations and by citizens themselves and is one of the important forms of realization of democracy and ways of involvement of population into society and government management;

3) Independent and established by the law kind of social control of competent subjects aimed at ensuring the regime of justice and legitimation in work of authorities.

According to the article 4 of the Law on public control we understand public control as work of subjects of public control exercised with the purpose to keep an eye on the work of governmental authorities, local self-administration, state and municipal organizations, other bodies and organizations that have separate public authorities corresponding the federal law, and also with the purpose of public monitoring, analysis and public assessment of issued acts and taken decisions.

Agreeing almost completely with the opinions of scientists, we let us assume that owing to objective reasons misuse of power authority and realization of its own interests to the detriment of public ones are characteristic for government. This proves that government is not ready to share the power. Such negative tendency leads to the changes of essence and social purpose of government; therefore there is a necessity of taking measures to limit the power. By these measures we mean control. To exercise such control we need to form and develop public control over the work of governmental authority and local self-administration. That is why we consider it necessary to note that in the definition given in the legislative act one can't find the explanation why there is a necessity of ensuring the regime of justice and legitimation as a result of efficient public control.

Thus being an essential part of management in any democratic state public control should be an effective mechanism of ensuring not only transparency of work of authorities but also efficiency of such work. Owing to public control, we achieve both the observance of law by all the subjects of law management and ensuring the high level of public participation in the processes of management, ensuring responsiveness to public opinion when taking decisions, which are planned to be realized (Stepanova, 2010).

Article 9 of the Law on public control refers the following public associations to the subjects of public control: Public Chamber of the Russian federation, Public chambers of regions of the Russian federation, Public chambers (councils) of municipalities, public councils under federal executive authorities, public councils under legislative (representative) and executive bodies of governmental authorities of regions of the Russian Federation. Along with this the following organizations can be formed with the purpose to exercise a social control in cases and order stipulated by law: public monitoring commissions (they exercise control over ensuring human rights in places of forced imprisonment), supervisory councils (they exercise control over work of state corporations), public inspectorates and groups of public control (they work together with governmental and municipal watchdog agencies), other organizational structures of public control. 
Thus, though it is possible for citizens, NGOs and special organizational structures to participate in public control the system of public control is concentrated only in public chambers and public councils for they are the only ones who are defined by law as the subjects of public control. Accordingly, the results of public monitoring that is the facts provided by journalistic inquiry or inquiry of human rights organizations are to undergo a certain filtration to be admitted by the officials (James \& Hatch, 2013).

It is necessary to note that defining Public Chamber of the Russian Federation, public chambers of regions of the Russian Federation, public chambers (councils) of municipalities as the subjects of public control the lawmaker attempted to formulate the corresponding levels of public control

1) Federal level (this level of public control is being exercised by Public Chamber of the Russian federation);

2) Regional (this level of public control is being exercised by public chambers of regions of the Russian Federation);

3) Municipal (by public chambers (councils) of municipalities).

Along with that the establishment of the fourth subject of social control-public councils under the authorities means that there is a specialized branch public control that also exists on the territorial level (for instance, public councils are functioning under the Ministry of Home Affairs of the Russian Federation and Ministry of Home Affairs of the Mari El Republic. These councils are competent to exercise public control over the corresponding governmental body).

As it has been noted in Article 13 of the Law on public control, it is indicated that public councils may be formed under the bodies of local self-government, which depends on the bodies of local self-government and is not compulsory for them. Thus, the lawmaker actually created such a situation when at present there are no mechanisms of organization of public control on municipal level: public chambers (councils) of municipalities are just to be formed when it is not compulsory to form public councils under the bodies of local self-government. It means that the whole level of government bodies remains de facto without public control (or public control is to be exercised through the mechanisms of the existing public chambers of the Russian Federation and its regions)

We suppose that the problem under discussion needs to be solved immediately on legislative level through the changes of version of the existing act. In particular, we consider it necessary to add the regulation "Public chambers (councils) of municipalities should have been formed by 1 January 2016. Before their formation public chamber of the corresponding region of Russian Federation be authorized with the function of public control" to Article of 12 of the Law on public control. In part 3 Article 13 of the Law on public control announce in the next publication "Public councils be formed under the bodies of local self-government of urban districts, urban districts with intracity division, metropolitan regions, urban areas (intracity municipalities), cities of federal significance by 1 January 2016. Public councils can be formed under the bodies of local self-government of other municipalities". We suppose that this modification is extremely important as it will let form subjects of public control in the field - under those bodies of local self-government that wouldn't like to have public control on the part of citizens of their territory. We think that this satisfies in the most optimal way the essence and legal nature of the institutions of public control and it will bring public control nearer to the citizens (Gilbert, 2010).

Speaking about the forms of public control it is necessary to point out that the Russian researchers Kochev and Averkiev determined the vast list of methods of its implementation: observation (for instance, during the sessions), analysis of official statistics and analysis of documents, on-site direct investigation (whether the announcements concerning the appointments with citizens are declared or not, whether there are ramps for disabled people or not and so on), investigation of conditions by visiting government bodies, acceptance of complaints and appeals, conversations, interviews, focus-groups polls, public examination, practical experiment (for instance, how to make an appointment with the representative of governmental body, with deputy), public inquest, public monitoring (Kocheva \& Averkiev, 2013).

The law defines that public control is being exercised and has such forms of public control as public monitoring, public inspection, and public examination. The control is also carried out in interconnection of institutions of civil society with the governmental bodies and institutions of local government. This interconnection has the form of public discussions, public hearings and others.

The carried out analysis shows that public control law provides the vast range of forms and methods of exercising public control over the institutions of local self-government. Absence among subjects of public control of such institutes of civil society, as mass media and public associations causes concern.

Speaking about mass media's functions in civil society it is worthwhile noting that A. Galkin determined the 
following ones: in the first place, uniting the society on the base of horizontal network links of information of this territory aimed at ensuring social integrity and historical succession of society development; in the second place, formation of mechanisms of the conciliation of the interests and conflict regulation; in the third place, socialization of individuals (Galkin, 2012).

Today mass media has the purpose of creating the instruments for a dialogue between the government, civil society and citizens. Therefore, we find it more suitable to cite Orlov's remark. He says that public structures of TV and radio broadcasting and the Internet afford the opportunities for participation in the dialogue with the government representatives (Orlov, 2012). We will add that in this context mass media is the instrument of publicity and openness. These are the principles on which the dialogue with the authorities in civil society should be made.

Grib called mass media the most effective way of public control over the government (Grib, 2010). Souslikov supports him saying that mass media becomes a more accessible and all-embracing instrument of public control in civil society (Souslikov, 2007). In this connection we pay attention to Konovchenko and Kisilev's idea. They say that mass media observing the executive power represents the people playing the role of legislative power. That is why mass media can claim to be called the "fourth power" (Konovchenko \& Kisilev, 2004).

Along with that Mikheeva analyzing the forms of participation of population in organization of public control noted that there are no mechanisms of implement of public control (Mikheeva, 2010). The analysis of the Law on public control proves this idea, for instance, the law doesn't include the key form of implement of public control exercised by mass media, that is the law doesn't reflect define public inquest as the form of public control which in our opinion deserves more attention. This form of public control consist in collection and analysis of information and facts related to the cases of violations of citizens' rights and legitimate interests, misuse of power on the part of authorities. As a rule, this form is applied in case when certain significant violations on the part of authorities and cases of misuse of power are revealed. Public inquest may have official and non-official status and nature.

The important condition of implement of public inquest is willingness of local governments to cooperate with public when the inquest is being carried out. As a rule, there are no considerable problems of interaction and cooperation of public and power when inquest is carried out in democratic country with strong civil society. As many Russian scientists accurately notice in countries where they start to base civil society and democratic principles of management the level of effectiveness of cooperation of citizens and power in carrying out public inquest remains extremely low. Local governments in certain cases sometimes interfere with such inquests. That is why one of the most important factors of the effective implement of public inquest is the following: mechanisms of implement of public inquest and formation of initiative groups, their authorities need to be accurately defined in Russian law. We suppose that it deserves the additional consideration for including in Federal Law "On the principles of public control".

Another aspect is considered to be no less important. The development of civil society and improvement of democracy is not possible without legislative consolidation of effective forms of interaction of institutions of local government with public associations functioning on local level. These associations' membership consists of active and responsible inhabitants of municipalities.

At present presenting the population's interests citizens' associations of special status called public associations along with the groups of citizens, inhabitants of the same area begin to play greater role in the process of preparation and state decisions making. Along with that lawmaking initiative is the important form of interaction of public associations with institutions of local government and form of public control. In a certain form lawmaking initiative as a form of population participation in implement of local self-government is consolidated in Federal Law "On general principles of local self-government organization in the Russian Federation". Among those who can put forward the lawmaking initiative in order stipulated by standard legal act of representative act of municipality there is an imitative group possessing electoral right.

In our opinion authorizing public associations with the right of lawmaking initiative on local level will allow to increase effectiveness of municipal legal acts for public associations accomplishing their work in concrete socially significant sphere know very well the problems of this region and correspondingly can propose legal ways of their solution. This will be one of the forms of public control over the institutions of local government.

The right of public associations to have a lawmaking initiative is not an invention of the present days. Article 113 of USSR constitution of 1977 says that public associations presented by the Union bodies have the right have a lawmaking initiative. 
At present public associations doesn't have such a right on federal level. However, in some regions of the Russian Federation in accordance with law they have the right of legislative initiative (Altai Republic, Samara, Kabardino-Balkaria).

Nowadays lawmaking initiative needs of public associations of the corresponding municipality reached crisis point.

Federal Law "On general principles of local self-government organization in the Russian Federation" calls public hearings as a form of participation of population in implement of local self-government. Possibility to hold public hearings for projects discussion of municipal legal acts on the problems of local significance with participation of inhabitants of municipality is stipulated by this law. Population, municipality representative body and the head of municipality have the initiative of holding these hearings.

It is also unjust that public associations are not included in the subjects with authority on initiative of holding public hearings. Public discussion of drafts of municipal legal acts on the problems of local significance is an important stage of local lawmaking. The final publication of legal act depends on this very stage. Certain citizens of municipalities often don't owe the developed civil responsibility which is characteristic of public associations.

In our opinion, there is objective need of publication of corresponding modifications in current federal law in this part. There is also need of authorizing public associations with initiative of holding public hearings. The following changes in Federal Law "On general principles of local self-government organization in the Russian Federation" will help solve the indicated problem:

1) Paragraph 1 of Article 26 in the next publication be as follows "Initiative groups of citizens possessing electoral right along with public associations of the municipality can put forward the lawmaking initiative in order stipulated by standard legal acts of representative body of municipality"

2) Paragraph 1 of Paragraph 2 of Article 28 in the next publication be as follows "Public hearings be held on initiative of citizens, public associations on the territory of the municipality, representative body of municipality or the head of municipality".

The mentioned law changes are aimed at improvement of mechanisms of interaction of public associations with institutions of local government and public control over their work. As Mikheev notices in his work that the institutions of territorial public self-administration, youth parliament, vigilante groups which are not included in the list of subjects of public control are developed (Mikheev, 2010). We find it necessary to note that it needs elaboration as well: it needs either increase of subjects of public control or arrangement of relations between the mentioned public formations, public chambers and public councils on the basis of cooperation agreement. In its turn this kind of solution of a problem gives rise to the plenty of unsettled problems and additional potentialities of public control.

\section{Conclusion}

Summing up the result of the conducted research, it is advisable to draw the following conclusions.

1) The law on the principles of public control established the system of public control in Russia in accordance with the levels of power (federal, regional, and municipal) and in accordance with the branches. Moreover the first kind of control is being exercised by the public chambers according to the territorial principle and the second one - by public councils under specific governmental body. However the lawmaker actually created such a situation when at present there are no mechanisms of organization of public control on municipal level.

The mechanism of cooperation of local authorities with public associations and mass media isn't settled. Public associations and mass media have to receive the status of subjects of public control. Also the institutions of territorial public self-administration, youth parliament, vigilante groups which are not included in the list of subjects of public control, but these institutes could participate in public control.

2) For formation of effective system of public control at the municipal level in the research are proved the legislative offer on creation public councils, which be formed under the bodies of local self-government of urban districts, urban districts with intracity division, metropolitan regions, urban areas (intracity municipalities), cities of federal significance.

3) The analysis of the Law on public control proves this idea, for instance, the law doesn't include the key form of implement of public control exercised by mass media, that is the law doesn't reflect define public inquest as the form of public control which in our opinion deserves more attention.

4) It's necessary to authorize public associations with the right of lawmaking initiative on local level and to authorize with the right to be initiator of public hearings. These conclusions are formulated in the form of 
legislative offers in this work.

In the current legislation there are gaps regarding formation of subjects of public control at the municipal level, which complicate formation of institute of public control. The theoretical and practical conclusions, formulated in research, are directed on elimination of these gaps and efficiency increase of participation of institutes of civil society in public control over the activities of local authorities.

\section{Acknowledgements}

The authors thank Mari State University where the research has been pursued, and the rector of Mari State University, Mikhail N. Shvetsov, for assistance in organizing the research.

\section{References}

Galkin, A. (2012). Civil society in theory and on the practice. Retrieved from $\mathrm{http}: / / w w w . l a w i n r u s s i a . r u / g r a z h d a n s k o e-o b s h c h e s t v o-v-t e o r i i-i-n a-p r a k t i k e$

Gilbert, L. (2010). Civil Society and Social Capital in Russia. International Encyclopedia of Civil Society, 7 , 273-278.

Grib, V. V. (2010). The media as an institution of civil society. Information Law, 1, 32-35.

Grib, V. V. (2010). Legislative (law-making) initiative as a form of civil society influence on public authorities. Constitutional and municipal law, 12, 9-15.

Hyden, G. (1997). Civil society, social capital, and development: Dissection of a complex discourse. Studies in Comparative International Development, 32(1), 3-30. http://dx.doi.org/10.1007/BF02696304

James, R., \& Hatch, W. F. (2013). Organizing Civil Society in Russia and China: A Comparative Approach. International Journal of Politics, Culture, and Society, 26(4), 323-347. http://dx.doi.org/10.1007/s10767-013-9148-5

Konovchenko, S. B., \& Kiselev, A. G. (2004). Information politics in Russia (p. 328). Moscow: RAGS.

Kocheva, O. (2013). Civilian control: notions and technology. Retrieved from http://control.prpc.ru/techn_01.shtml

Mikheev, D. S. (2010). About problems of interaction of public institutes with institutions of local government. Gaps in Russian legislation, 4, 29-30.

Mikheev, D. S. (2014). Legal Analysis of the European Charter of the Local Seif-Government in The Light of the Principle of Publicity. Life Science Journal, 11(6), 620.

Mikheeva, T. N., \& Yaichnikova, J. S. (2010). About some forms of the population of municipal union in the control over institutions local government. Gaps in Russian legislation, 4, 20-22.

Orlova, K. A. (2012). The media as part of civil society. Bulletin of the South Ural State University, 30(20), 13-17.

Stepanova, A. (2010). Comparative analysis of cooperation mechanisms between power authorities and civil society institutions: By the cases of Russia and Great Britain. International Review on Public and Nonprofit Marketing, 7(1), 97-99. http://dx.doi.org/10.1007/s12208-010-0045-6

Suslikov, S. A. (2007). Constitutional and legal regulation of the media in the Russian Federation (p. 188). Saratov.

\section{Copyrights}

Copyright for this article is retained by the author(s), with first publication rights granted to the journal.

This is an open-access article distributed under the terms and conditions of the Creative Commons Attribution license (http://creativecommons.org/licenses/by/3.0/). 